\title{
Hypoxia-Inducible Factor (HIF) as a Pharmacological Target for Prevention and Treatment of Infectious Diseases
}

Tamara Bhandari $\cdot$ Victor Nizet

To view enhanced content go to www.infectiousdiseases-open.com

Received: February 15, 2014 / Published online: June 24, 2014

(C) The Author(s) 2014. This article is published with open access at Springerlink.com

\section{ABSTRACT}

In the present era of ever-increasing antibiotic resistance and increasingly complex and immunosuppressed patient populations, physicians and scientists are seeking novel approaches to battle difficult infectious disease conditions. Development of a serious infection implies a failure of innate immune capabilities in the patient, and one may consider whether pharmacological strategies exist to correct and enhance innate immune cell function.

Electronic supplementary material The online version of this article (doi:10.1007/s40121-014-0030-1) contains supplementary material, which is available to authorized users.

T. Bhandari $\cdot$ V. Nizet $(\bowtie)$

Center for Immunity, Infection and Inflammation, Department of Pediatrics and Biomedical Sciences Graduate Program, University of California, San

Diego, La Jolla, USA

e-mail: vnizet@ucsd.edu

V. Nizet

Skaggs School of Pharmacy and Pharmaceutical Sciences, University of California, San Diego, La Jolla, USA

\section{Nizet}

Center for Immunity, Infection and Inflammation, Medical Sciences Research 4113, University of California, San Diego, 9500 Gilman Drive, MC 0760, La Jolla, CA 92093-0760, USA
Hypoxia-inducible factor-1 (HIF-1), the central regulator of the cellular response to hypoxic stress, has recently been recognized to control the activation state and key microbicidal functions of immune cells. HIF-1 boosting drugs are in clinical development for anemia and other indications, and could be repositioned as infectious disease therapeutics. With equal attention to opportunities and complexities, we review our current understanding of HIF-1 regulation of microbial host-pathogen interactions with an eye toward future drug development.

Keywords: Bacteria; Dendritic cells; Hypoxiainducible factor; Innate immunity; Macrophages; Neutrophils; T cells; Virus

\section{INTRODUCTION}

The golden age of antibiotics may be nearing its end, as more and more pathogens acquire resistance to an ever-widening range of antibiotics. New ways to prevent and treat infectious diseases are urgently needed. One possible solution is to focus on the other side of 
the host-pathogen equation-not killing the invaders, but strengthening the defenses. Just as vaccines harness the power of the adaptive immune system to prevent infectious disease, treatments that activate the innate immune system could potentially help to cure acute infections. Hypoxia-inducible factor (HIF)-a transcriptional regulator that controls the key aspects of the immune response-is a promising target for such immune-boosting treatments. HIF regulates the energy generation and production of multiple microbicidal effectors of phagocytic cells including neutrophils and macrophages, and established pharmacological strategies exist to increase cellular HIF levels. But one must proceed prudently, since a growing body of research reveals that HIF plays multiple roles in immune regulation, with differing effects in different cell types. Strategies to modulate HIF levels for infectious disease therapy must take these complexities into consideration.

\section{HIF BIOLOGY AND REGULATION}

Hypoxia-inducible factor is a basic helix-loophelix transcription factor [1] first identified for its role in erythropoietin regulation [2], but later discovered to also regulate genes involved in glycolysis, angiogenesis, cell differentiation, apoptosis, and other cellular pathways [3]. HIF is a heterodimer composed of a HIF- $\alpha$ subunit and HIF- $1 \beta$ subunit. Hif- $a$ is actually a family of three genes: Hif1a, Hif2a, and Hif3a. HIF-3 $\alpha$ is distantly related to HIF- $1 \alpha$ and HIF- $2 \alpha$ and little is known about its function, although it may inhibit the activity of HIF- $1 \alpha$ and HIF-2 $\alpha$ [4]. The HIF- $1 \alpha$ and HIF- $2 \alpha$ subunits are closely related, sharing $48 \%$ overall amino acid identity [5]. The two subunits are very similar in their DNA binding and dimerization domains but differ in their transactivation domains, implying that they may regulate unique sets of target genes [5]. Whereas HIF- $1 \alpha$ is ubiquitously expressed, HIF- $2 \alpha$ is most abundantly expressed in vascular endothelial cells during embryonic development and in endothelial, lung, heart [6], and bone marrow cells [7] in the adult. HIF- $2 \alpha$ levels are closely correlated with vascular endothelial growth factor (VEGF) mRNA expression [6] and are frequently elevated in solid tumors [7], suggesting that its most important functions may lie in vascularization [6]. Since only a small fraction of published research focuses specifically on HIF- $2 \alpha$ or HIF$3 \alpha$, this review will be restricted primarily to HIF- $1 \alpha$.

In the presence of oxygen and the absence of inflammatory stimuli, the level of HIF- $\alpha$ is kept low by two mechanisms. In one, HIF- $\alpha$ is hydroxylated by prolyl hydroxylases [8]. The hydroxylated HIF- $\alpha$ is recognized by the ubiquitin ligase von Hippel-Lindau factor (vHL), which ubiquitinates HIF- $\alpha$, targeting it for destruction via the proteasome [9]. In the second mechanism, factor inhibiting HIF (FIH) hydroxylates HIF- $\alpha$, blocking its ability to associate with p300-CREB binding protein (CREB-BP), which in turn inhibits the ability of the HIF complex to bind DNA and promote transcription [10]. When oxygen tension is low, neither hydroxylation event occurs, HIF- $\alpha$ and HIF-1 $\beta$ dimerize, combine with CREB-BP and bind to hypoxia-response elements (HRE) in the promoter regions of over a hundred target genes [3].

The NF- $\kappa$ B pathway appears to be crucial for the induction of HIF in response to hypoxia [11]. The human HIF-1 $\alpha$ promoter contains a canonical NF- $\kappa B$ binding site $-197 /-188$ base pairs upstream of the transcriptional start site, the mutation of which leads to a loss of hypoxic HIF-1 $\alpha$ upregulation [11]. There is evidence that NF- $\kappa B$ family members bind to the HIF- $1 \alpha$ promoter [12], and the endogenous inhibitor 
of NF- $\kappa \mathrm{B}, \quad \mathrm{I} \kappa \mathrm{B} \alpha$, derepresses HIF-1 by sequestering FIH [13]. Basal NF- $\kappa \mathrm{B}$ activity is required for HIF- $1 \alpha$ protein accumulation under hypoxia in cultured cells and in the liver and brain of hypoxic animals [11]. IKK- $\beta$ deficiency results in defective induction of HIF- $1 \alpha$ target genes including VEGF. IKK- $\beta$ is also essential for HIF- $1 \alpha$ accumulation in macrophages during the response to bacterial infection. Hence, IKK- $\beta$ is an important physiological contributor to the hypoxic response, linking it to innate immunity and inflammation [11].

Though HIF was first identified and named for its role in hypoxia, later work showed that a variety of molecular signals of infection and inflammation may increase HIF activity even under normoxic conditions. Growth hormones such as insulin-like growth factor [14], cytokines such as interleukin-1 $\beta$ (IL-1 $\beta$ ) [15] and viral proteins [16] all activate HIF. This regulation can occur at the transcriptional, translational, or post-translational levels. For example, lipopolysaccharide (LPS) induces Hif1a mRNA expression in a toll-like receptor 4 (TLR4)-dependent manner that involves members of the NF- $\mathrm{BB}$, mitogen-activated protein kinase (MAPK), and extracellular signal-regulated kinase (ERK) pathways [1719]. TLR7/8 ligation also leads to Hif1a transcript accumulation [20] and to protein stabilization in macrophages $[20,21]$.

Cytokines, on the other hand, often increase HIF activity by post-translational mechanisms. TGF- $\beta 1$ enhances HIF- $1 \alpha$ protein stability by inhibiting the expression of prolyl hydroxylase 2 (PHD2), which hydroxylates HIF and targets it for proteolytic destruction [22]. Tumor necrosis factor- $\alpha$ (TNF- $\alpha)[23]$ and IL-1 $\beta[15,24]$ induce HIF- $1 \alpha$ protein stabilization in an NF- $\kappa B-$ dependent mechanism without affecting its mRNA level.

\section{HIF AS A REGULATOR OF IMMUNE FUNCTION}

Why should a ubiquitous transcription factor be induced by both hypoxia and molecular signals of infection? Tissue foci of inflammation represent hypoxic microenvironments, with oxygen tensions measured under 1\% [25]. Hypoxia reflects increased metabolic demands due to a high density of inflammatory cells and microorganisms, and limited perfusion because of thrombosis, damage to the vasculature, or compression of blood vessels due to interstitial hypertension. Immune cells, therefore, need to be able to carry out their functions under conditions of reduced oxygen tension, a situation made even more challenging since many leading bacterial pathogens proliferate readily even in anaerobic microenvironments. Since infection and hypoxia are so often encountered together, it perhaps stands to reason that HIF would be induced not only by hypoxia but also in response to a broad range of infections: viral, bacterial, protozoan, and fungal [26, 27].

\section{HIF IN REGULATION OF INNATE IMMUNITY}

Hypoxia-inducible factor has been proposed as a master regulator of innate immunity [28]. HIF expression in epithelial cells can control the release of chemoattractants that recruit neutrophils to the site of infection or inflammation. Dendritic cells (DCs) exposed to hypoxia upregulate genes coding for proteins chemotactic for neutrophils such as chemokine (C-X-C motif) ligand (CXCL)2, CXCL3, CXCL5, and CXCL8 [29]. HIF induces $\beta 2$ integrin expression in neutrophils [30], and Cdc42 and Rac1 expression in macrophages [31], 
enhancing migration of both cell types to the site of infection. Hypoxia also increases CXC chemokine receptor (CXCR)4 [32] and inhibits CC chemokine receptor (CCR)5 [33] expression in macrophages in a HIF-dependent manner, which increases retention of macrophages at the site of infection.

Not only are more immune cells recruited and retained, but those cells live longer. HIF extends the functional neutrophil lifespan by inhibiting apoptotic pathways in an NF-кBdependent manner [34, 35]. People with mutations in $\mathrm{vHL}$-and therefore constitutively elevated HIF levels-have neutrophils with longer lifespans. Hypoxia also promotes survival of monocytes and macrophages [36]. HIF transcriptional regulation also supports other phenotypes related to immune cell activation. Hypoxia leads to TLR-2, TLR-4, and TLR-6 upregulation in a HIF-dependent manner [37, 38], enhancing the detection of pathogen-associated molecular patterns. Hypoxic myeloid cells from mice exhibit increased phagocytosis [39], and those from humans who have mutations in vHL have increased phagocytic capacity as well [40].

In an in vivo model of innate infection, mice lacking HIF- $1 \alpha$ in myeloid cells had diminished capacity to fight off a skin infection with the pathogen group A Streptococcus (GAS) [41]. Hif1a knockdown by siRNA also led to more severe corneal disease in mice infected intraocularly with Pseudomonas aeruginosa, and this effect was due to impaired neutrophil function [42]. Conversely, mice in which HIF was elevated by drug treatment were better able to control skin infection by methicillin-resistant Staphylococcus aureus (MRSA) [43, 44]. Overall, augmenting HIF in macrophages increases bactericidal activity by increasing the production of a wide range of antimicrobial factors $[43,44]$. Hypoxia leads myeloid cells to release more nitric oxide (NO), granule proteases, antimicrobial peptides, and proinflammatory cytokines [41, 45]. One notable exception is superoxide generation via the oxidative burst, which appears to transpire with equal efficiency in wild type and Hif1a null macrophages [41]. It is perhaps logical that the enzymatic pathway for superoxide generation is not elevated during hypoxia, given that it requires the presence of oxygen, which is by definition in short supply. HIF has also been recognized to promote the production of neutrophil [46] and mast cell [47] extracellular traps, a specialized process whereby nuclear DNA and histones are released at tissue foci of infection to help ensnare and kill bacteria.

\section{DENDRITIC CELLS AND PRIMING THE ADAPTIVE IMMUNE RESPONSE}

Some innate immune cells' also play a crucial role in priming the adaptive immune response through their antigen-presenting functions. Dcs, closely related to the macrophage, serve a pre-eminent role as antigen-presenting cells (APCs). As such, they provide three signals to $\mathrm{T}$ cells: the antigen, presented in the context of major histocompatibility complex (MHC)-I or MHC-II; co-stimulatory signals through ligation of surface molecules; and cytokines and other soluble mediators. The combination of signals alerts the $\mathrm{T}$ cells to the foreign antigen, activates them, and modulates the strength and polarization of the adaptive immune response. DCs are a functionally and phenotypically diverse group of cells. They can be derived from the myeloid or lymphoid lineages [48]. Myeloid DCs can be classified as pre-dendritic cells (pre-DCs), conventional dendritic cells (cDCs), and inflammatory dendritic cells 
(iDCs); cDCs can be further divided into migratory and lymphoid tissue-resident dendritic cells.

Pre-DCs are cells without the classic dendritic form and antigen-presenting function, but with a capacity to develop into DCs with little or no division. An inflammatory or microbial stimulus might be required. For example, monocytes can be considered pre-DCs because they can give rise to inflammatory DC upon exposure to inflammatory stimuli [49]. cDCs already have DC form and function. Migratory DCs fit the profile of the textbook DCs, and can be immature or mature. Lymphoid tissue-resident cDCs collect and present foreign and self-antigens in their home organ; these cells play crucial roles in maintaining tolerance to self-antigens, harmless environmental antigens, and commensal microorganisms. iDCs are specialized for antigen capture and processing and have limited ability to stimulate $\mathrm{T}$ cells. Under steady-state conditions, iDCs mostly reside at sites of contact between the host and the environment, such as the skin and the respiratory or gastrointestinal mucosa. These sentinel cells continuously scan the surroundings for the presence of pathogenassociated molecular patterns (PAMPs) or damage-associated molecular patterns (DAMPs). Upon antigen uptake and activation by proinflammatory cytokines and DAMPs or PAMPs, iDCs undergo phenotypic and functional changes called maturation.

Maturation prepares the DC to fulfill the second half of their sentinel duty: to take the antigens they had previously captured while immature to the lymph nodes and present them to $\mathrm{T}$ cells. At the molecular level, maturation manifests as increased expression of MHC antigens and co-stimulatory molecules (such as CD83, CD80, CD86, and CD40), decreased expression of phagocytic/endocytic receptors, and a switch in the chemokine receptor repertoire to downregulate receptors for inflammatory chemokines (e.g., CCR1, CCR2, CCR5, CCR6, and CXCR1) and upregulate receptors for chemokines required for homing to secondary lymphoid organs, namely CCR7 and CXCR4.

\section{DENDRITIC CELLS AND HIF}

Research into the role of HIF in DCs is complicated by the fact that DCs are a rare cell type and it is difficult to obtain adequate numbers of primary cells for experimentation. Consequently, much of the in vitro work on DCs and HIF has been performed on human peripheral blood monocytes or mouse bone marrow cells differentiated into DCs by treatment with granulocyte-macrophage colony stimulating factor (GM-CSF) and IL-4 for periods of 7-11 days. Both methods produce DCs most similar to iDCs [50], and not the migratory cDCs that are likely to play an important sentinel role in vivo.

Previous attempts to determine the role of HIF in DC maturation have yielded contradictory results. Various investigators have produced data indicating that hypoxia promotes DC maturation both alone [51, 52], and in combination with LPS stimulus $[53,54]$, as measured by decreased phagocytosis $[55,56]$, increased migration [57, 58], and increased expression of $\mathrm{MHC}$ and co-stimulatory molecules [54, 56, 57, 59]. Others have come to exactly the opposite conclusion, namely, that hypoxia inhibits DC maturation [55], migration [60, 61] (possibly by reducing expression of MMP-9, which helps DC migrate $[62,63])$, and expression of co-stimulatory molecules [60, 64, 65]. 
When it comes to the effect of hypoxia and HIF on the ability of APC to prime T cells, the literature is no less mixed. Some groups have shown that hypoxia and HIF increase the ability of APCs to stimulate a T-cell response [53, 56, $66,67]$ and lead to the expression of more proinflammatory cytokines $[53,59,60,64,65$, $68,69]$ that bias toward a $\mathrm{T}_{\mathrm{H}} 1$ response [66], and type I interferons [70], which are essential for the ability of DC to induce $\mathrm{T}_{\mathrm{H}} 1$ differentiation [71]. Others have found the opposite [55, 72]. Still others have reported a mixed phenotype among the DC in their in vitro model system [60].

From the above literature survey, the jury is still out on the role of HIF in priming the adaptive immune response. Some of the variation in reported results may be due to differences in stimuli. Critically, the context within which HIF is activated (hypoxia versus inflammation) affects the results of HIF activation. When HIF is activated by hypoxia, it enhances transcription from a different set of target genes than when it is activated by a TLR ligand such as lipopolysaccharide (LPS) [73]. Hypoxia and LPS stabilize HIF through different pathways; LPS-induced HIF stabilization requires both NF- $\mathrm{kB}$ and MyD88, while hypoxia-induced HIF stabilization is independent of NF- $\kappa \mathrm{B}$ [73]. Furthermore, when hypoxia is used as a stimulus in the antigen presentation readouts, it affects not only the APC but the $\mathrm{T}$ cells themselves, further influencing the results of the experiments.

\section{HIF REGULATION IN T CELLS}

Intriguingly, HIF appears to have certain opposing effects on lymphoid cells of the adaptive immune system when compared to the properties it exhibits with myeloid cells of the innate immune system. Hypoxia and HIF- $1 \alpha$ elevation reduces T-cell survival $[74,75]$ and proliferation [75, 76]. Hypoxia also inhibits T-cell activation by upregulating the inhibitory isoform I.1 of HIF-1 $\alpha$ [77]. When isoform I.1 was deleted in $\mathrm{T}$ cells, the overall ability to fight infection was improved, with reduced bacterial load, increased resistance to sepsis, enhanced M1 macrophage polarization, and the release of more proinflammatory cytokines and less of the anti-inflammatory IL-10 [78]. Other researchers showed that loss of HIF- $1 \alpha$ in T cells led to an increase in IFN $\gamma$ secretion by both $\mathrm{CD}^{+}$and $\mathrm{CD}^{+} \mathrm{T}$ cells [79].

Hypoxia and HIF play an important role in tipping the balance between regulatory $\mathrm{T}$ cells $\left(\mathrm{T}_{\text {reg }}\right)$ and $\mathrm{T}_{\mathrm{H}} 17$ cells towards the $\mathrm{T}_{\text {reg lineage. }}$ $\mathrm{T}_{\text {regs }}$ and $\mathrm{T}_{\mathrm{H}} 17$ cells derive from naïve $\mathrm{CD} 4^{+} \mathrm{T}$ cells, with $\mathrm{T}_{\text {regs }}$ characterized by expression of the transcription factor Foxp3 [80] and $\mathrm{T}_{\mathrm{H}} 17 \mathrm{~s}$ characterized by the expression of ROR $\gamma \mathrm{T}$ [81]. Hypoxia leads to induction of Foxp3 in a HIFdependent manner [82] and increased numbers of $\mathrm{T}_{\text {regs }}$ in vivo [82] and more potent $\mathrm{T}_{\text {regs }}$ in vitro [83]. Knockout of Hifla in $\mathrm{CD}^{+}{ }^{+}$cells leads to an increase in the numbers of $\mathrm{T}_{\mathrm{H}} 1$ and $\mathrm{T}_{\mathrm{H}} 17$ cells [84]. Others have found that differentiating naïve $\mathrm{CD}^{+} \mathrm{T}$ cells under hypoxia followed by re-oxygenation increases the number of $\mathrm{T}_{\mathrm{H}} 17$ cells [85], and that Hif1a knockout in $\mathrm{CD}^{+}{ }^{+} \mathrm{T}$ cells results in increased $\mathrm{T}_{\text {regs }}$ and fewer $\mathrm{T}_{\mathrm{H}} 17$ cells [86], possibly by transcriptional activation of $\operatorname{ROR} \gamma \mathrm{T}$ and degradation of Foxp3 [86]. However, these latter studies looked at the effect of HIF in the presence of IL-6, which biases toward a $\mathrm{T}_{\mathrm{H}} 17$ response, or using the autoimmune disease model of experimental autoimmune encephalomyelitis, which creates the same bias $[86,87]$. In the absence of conditions that bias toward the development of $\mathrm{T}_{\mathrm{H}} 17, \mathrm{~T}_{\text {regs }}$ are produced [82]. 


\section{COMPLEX EFFECTS OF HIF IN THE IMMUNE RESPONSE TO INFECTION}

Taken together, the research suggests that HIF positively regulates the activity of innate immune cells but negatively regulates the activity of $\mathrm{T}$ cells, with effects on APCs that still require experimental clarification. Kominsky et al. [88] have argued that the differential HIF response mechanisms in myeloid cells versus $T$ cells has to do with the fundamental metabolism exhibited by each cell type. Myeloid lineage cells tend to glycolysis, whereas lymphoid lineage cells tend to oxidative phosphorylation [88]. HIF, which promotes glycolysis in the absence of sufficient oxygen for oxidative phosphorylation, would therefore be most important for supporting glycolysis in myeloid cells, which are best adapted for taking advantage of increased glycolysis. Conversely, supporting glycolysis in lymphoid cells may be a less-effective way of increasing their metabolic activity. DC can belong to either lineage; the sometimes contradictory research studies discussed above have all been performed using experimental models of myeloid DC. The hypoxia-induced reduction in T-cell activity and increase in the development of $\mathrm{T}_{\text {regs }}$ may aid in preventing an uncontrolled immune response that provokes autoimmunity or pathological tissue damage.

\section{MANIPULATION OF HIF BY PATHOGENS}

Hypoxia-inducible factor induction is a general part of the host response to infection. HIF is induced in response to both Gram-positive and Gram-negative bacteria [11, 41], as well as by viruses [89, 90], protozoa [27], and fungi [27].
Given the centrality of HIF in the immune response, it should come as no surprise that some pathogens have developed immune evasion strategies to counteract HIF. For example, oncolytic reovirus can prevent accumulation of HIF- $1 \alpha$ in a proteasomedependent manner, without affecting Hif1a transcription [91]. Moloney murine leukemia virus is able to prevent HIF-1 $\alpha$ protein accumulation in infected mice without affecting Hif1a gene transcription by reducing the levels of the HIF-stabilizing host protein Jab1 [92]. Chlamydia pneumoniae degrades HIF by secreting the chlamydial protease-like activity factor into the cytoplasm of infected cells [93]. Pseudomonas aeruginosa expresses alkyl quinolones that target the HIF- $1 \alpha$ protein for proteasomal degradation [94].

Infections by certain other viral pathogens may increase HIF levels or activity, perhaps exerting an anti-apoptotic effect that promotes survival of the host cell they are infecting. The carboxy terminus of HBx from hepatitis B virus was shown to enhance the transactivation of HIF- $1 \alpha$ by enhancing its association with CREBBP [95]. The Kaposi's sarcoma-associated herpesvirus (KSHV) expresses a protein known as latency-associated nuclear antigen (LANA), which targets vHL for degradation via ubiquitination, thereby increasing HIF protein levels [96], and another part of LANA promotes HIF nuclear accumulation [96]. Epstein-Barr virus (EBV) oncoprotein latent membrane protein 1 (LMP1) activates HIF-1 $\alpha$ by upregulating Siah1 E3 ubiquitin ligase by enhancing its stability, which allows it to increase the proteasomal degradation of prolyl hydroxylases 1 and 3 that normally mark HIF$1 \alpha$ for degradation [97]. As a result, LMP1 prevents formation of the vHL/HIF complex, and HIF is not degraded. 
Other viral and parasitic organisms are able to subvert HIF activity to their own benefit. HIF$1 \alpha$ stimulates the transcription of HIV-1 genes by associating with HIV-1 long terminal repeat [98], and the JCV polyomavirus genes by binding to the early promoter of the virus [99]. Other viruses may be sensing HIF as a marker of cellular stress to indicate when it is appropriate to exit the cell. Murid herpesvirus 4 [100] and EBV [101] switch from lysogenic to lytic when HIF levels are high. High levels of HIF lead to the expression of platelet-activating factor, which some pathogens then use to increase translocation across the intestinal epithelium [102]. Toxoplasma gondii survives better when HIF is elevated [103]. Toxoplasma induces HIF stabilization via activin-like receptor kinase signaling [104]. Leishmania, too, survives better when HIF is elevated, and HIF inhibition reduces survival of the parasite [105, 106].

\section{HIF FOR PREVENTION AND TREATMENT OF INFECTIOUS DISEASE}

As a master regulator of innate immunity, HIF stands as a promising target for fine-tuning the immune response. In most infections, increasing HIF levels could be expected to boost diverse myeloid cell antimicrobial activities and promote clearance of infection. Under certain conditions, particularly among viral pathogens, HIF stabilization may promote the extended survival of infected cells, therefore care must be taken in determining when HIF augmentation can be a beneficial strategy.

Along with in vitro work showing that HIF increases the bactericidal capacity of immune cells, it has also been found that treating mice with the HIF stabilizers mimosine [43] or AKB-
4924 [44] improves their ability to fight skin infections. While HIF-boosting agents (prolyl hydroxylase inhibitors) are in advance clinical trials for anemia due to their ability to boost erythropoietin production [107], no trials in humans have been initiated to date in which drugs that upregulate HIF are used to treat acute bacterial infection. Nonetheless, such a strategy could be effective for difficult clinical scenarios such as opportunistic bacterial infections in patients with weakened immune systems or with pathogens exhibiting multidrug resistance to conventional antibiotics. Theoretically, HIF boosting may also have an advantage in reducing the likelihood of drug resistance; it would be prohibitively difficult for bacteria to evolve resistance to the whole arsenal of antimicrobial factors that are increased when HIF activity increases [3].

For those scenarios in which bacteriologic control is easily achievable by conventional antibiotics and in which pathology is being driven by an overactive immune response to bacterial components, HIF induction would have unclear utility. In noninfectious experimental LPS-induced sepsis, for example, which provokes an immunopathological cytokine storm, knocking out HIF in either myeloid cells [108] or T cells [109] reduces the severity of disease. This is in agreement with clinical research showing that septic patients exhibit reduced levels of HIF- $1 \alpha$ mRNA with an inverse relationship between mRNA level and disease severity [110].

Inflammatory bowel disease, which involves a complex interaction between epithelial barrier function, mucosal immune response and the normal colonic flora, has emerged as a promising therapeutic target for HIF-1 boosting. Treatment of mice with HIF-boosting agent AKB-4924 provided protection from 
chemical-induced colitis [111]. Treatment was associated with a 50-fold decrease in serum endotoxin in this model, along with reduction in cytokines proinflammatory cytokines IL-1 $\beta$, IL-6, and TNF- $\alpha$, while increasing the antiinflammatory cytokine IL-10; such protection was not seen in colonic epithelial-specific HIF-1deficient mice, implicating epithelial HIF-1 as the tissue target for AKB-4924-mediated protection. Intestinal inflammation involves a rapid accumulation of neutrophils at the colonic mucosa. The transmigrating neutrophils rapidly deplete oxygen in the local microenvironment, stabilizing intestinal epithelial HIF levels. Mice with chronic granulomatous disease, deficient in reactive oxygen species (ROS) generation, have exaggerated neutrophil recruitment and colitis, but pharmacological HIF stabilization with AKB-4924 protected these animals from severe colitis [112].

For viral infections, the landscape may be more complicated. On the one hand, HIF is a positive regulator of key immune response effectors against viral infections, just as against bacterial ones. On the other hand, since high HIF levels encourage certain lysogenic viruses to become lytic, activating HIF may potentially influence reactivation phenotypes. Also, HIF treatment in vivo could influence the antiviral activity of plasmacytoid DCs (pDCs), and one group has shown that HIF- $1 \alpha$ is a negative regulator of $\mathrm{pDC}$ development in vitro and in vivo [113].

The work in APCs suggests that HIF elevation could be effective not only in treating but also in preventing disease, through examination of adjuvant characteristics. To take advantage of the positive role of HIF in innate immune cells and avoid the negative effect of HIF on T cells, a HIF-stabilizing agent would have to be effective in the first hours of the immune response, but be exhausted by $24-48 \mathrm{~h}$ after immune stimulation when $\mathrm{T}$ cells begin activating. We have recently reported [114] proof-of-concept experiments using the HIF stabilizer AKB-4924 to strengthen the response to vaccination with ovalbumin, a model antigen. In this work, DC of mice treated with AKB-4924 showed increased MHC and co-stimulatory molecule expression and induced greater T-cell proliferation, and higher titers of antibodies were generated in mice provided the HIF-1 stabilizing agent. Further research must be done to determine whether a HIF-1 boosting drug could be developed fruitfully as a vaccine adjuvant.

It is important to recognize that both HIF- $1 \alpha$ and HIF- $2 \alpha$ are expressed in myeloid cells, and many drugs, including iron-chelating agents such as mimosine and desferioxamine, that target HIF-1 would affect HIF-2 similary. A potential exception to this rule is AKB-4924, which appears to preferentially stabilize HIF- $1 \alpha$ [44]. The conclusions in this review were drawn based mostly on work that exclusively analyzed HIF- $1 \alpha$ without specific analysis performed to ascertain changes in HIF- $2 \alpha$ level. While HIF-1 and HIF-2 have different tissue expression patterns and play distinct roles in several processes such as embryonic development and iron homeostasis [115], but their roles in the immune response to infection appear to be very similar (our own unpublished data and $[115,116])$. One way in which HIF-1 and HIF-2 are known to have different effects on the immune response is in regulation of the neutrophil chemoattractant IL-8. Overexpression of HIF-2 $\alpha$ increases IL-8 expression in endothelial cells [117], and siRNA knockdown of Hif2a reduces IL-8 expression [118], while HIF-1 $\alpha$ overexpression decreases IL-8 expression [119]. Researchers have shown, however, that hypoxia, which 
stabilizes both HIF-1 and HIF-2, results in reduced IL-8 expression [117], suggesting that the HIF-1 response is more influential than HIF-2 in IL-8 regulation and that a pharmacological agent targeting both isoforms would predominantly mirror the HIF-1 effect.

\section{SUMMARY}

Hypoxia-inducible factor, which exerts transcription control over immune cell energy generations and key effectors of the innate and adaptive immune response, represents a molecularly accessible and intriguing target for immune-boosting therapeutics. HIF stabilization in macrophages, neutrophils and epithelial cells can increase levels of key antibacterial factors including antimicrobial peptides, nitric oxide and proinflammatory cytokines. HIF-stabilizing agents also boosts DC antigen presentation and T-cell priming and provide barrier protective and immunomodulatory functions in inflammatory colitis. Yet differing effects of HIF modulation in $\mathrm{T}$ lymphocytes may pose complexities in the arena of antiviral therapy. Further exploration of the disease spectrum for which application of HIF modulation could serve as an adjunctive therapy to classical antiinfective therapeutics is warranted.

\section{ACKNOWLEDGMENTS}

All named authors meet the ICMJE criteria for authorship for this manuscript, take responsibility for the integrity of the work as a whole, and have given final approval for the version to be published. Work in the Nizet Laboratory on HIF and phagocyte function during bacterial infection has been funded by NIH grant A1093451.
Conflict of interest. Tamara Bhandari declares no conflict of interest.

Victor Nizet has collaborated on NIH and DOD grants with Aerpio Therapeutics, a developer of prolyl hydroxylase inhibitor drugs for inflammatory bowel disease and other medical applications.

Compliance with ethics. This review is based on previously conducted studies, and does not involve any new studies of human or animal subjects performed by any of the authors.

Open Access. This article is distributed under the terms of the Creative Commons Attribution Noncommercial License which permits any noncommercial use, distribution, and reproduction in any medium, provided the original author(s) and the source are credited.

\section{REFERENCES}

1. Wang GL, Jiang BH, Rue EA, Semenza GL. Hypoxiainducible factor 1 is a basic-helix-loop-helix-PAS heterodimer regulated by cellular $\mathrm{O} 2$ tension. Proc Natl Acad Sci USA. 1995;92:5510-4.

2. Semenza GL, Wang GL. A nuclear factor induced by hypoxia via de novo protein synthesis binds to the human erythropoietin gene enhancer at a site required for transcriptional activation. Mol Cell Biol. 1992;12:5447-54.

3. Nizet V, Johnson RS. Interdependence of hypoxic and innate immune responses. Nat Rev Immunol. 2009;9:609-17.

4. Heikkila M, Pasanen A, Kivirikko KI, Myllyharju J. Roles of the human hypoxia-inducible factor (HIF)$3 \alpha$ variants in the hypoxia response. Cell Mol Life Sci. 2011;68:3885-901.

5. Tian H, McKnight SL, Russell DW. Endothelial PAS domain protein 1 (EPAS1), a transcription factor selectively expressed in endothelial cells. Genes Dev. 1997;11:72-82.

6. Ema M, Taya S, Yokotani N, Sogawa K, Matsuda Y, Fujii-Kuriyama Y. A novel bHLH-PAS factor with 
close sequence similarity to hypoxia-inducible factor $1 \alpha$ regulates the VEGF expression and is potentially involved in lung and vascular development. Proc Natl Acad Sci USA. 1997;94:4273-8.

7. Talks KL, Turley H, Gatter KC, Maxwell PH, Pugh CW, Ratcliffe PJ, et al. The expression and distribution of the hypoxia-inducible factors HIF$1 \alpha$ and HIF- $2 \alpha$ in normal human tissues, cancers, and tumor-associated macrophages. Am J Pathol. 2000;157:411-21.

8. Ivan M, Kondo K, Yang H, Kim W, Valiando J, Ohh $\mathrm{M}$, et al. HIF $\alpha$ targeted for VHL-mediated destruction by proline hydroxylation: implications for O2 sensing. Science. 2001;292:464-8.

9. Jaakkola P, Mole DR, Tian YM, Wilson MI, Gielbert J, Gaskell SJ, et al. Targeting of HIF- $\alpha$ to the von Hippel-Lindau ubiquitylation complex by $\mathrm{O}_{2}$ regulated prolyl hydroxylation. Science. 2001;292:468-72.

10. Ebert BL, Bunn HF. Regulation of transcription by hypoxia requires a multiprotein complex that includes hypoxia-inducible factor 1 , an adjacent transcription factor, and p300/CREB binding protein. Mol Cell Biol. 1998;18:4089-96.

11. Rius J, Guma M, Schachtrup C, Akassoglou K, Zinkernagel AS, Nizet $\mathrm{V}$, et al. NF- $\kappa \mathrm{B}$ links innate immunity to the hypoxic response through transcriptional regulation of HIF-1 $\alpha$. Nature. 2008;453:807-11.

12. Taylor CT, Cummins EP. The role of NF-kappaB in hypoxia-induced gene expression. Ann NY Acad Sci. 2009;1177:178-84.

13. Shin DH, Li SH, Yang S-W, Lee BL, Lee MK, Park $\mathrm{J}-\mathrm{W}$. Inhibitor of nuclear factor- $\kappa \mathrm{B}$ alpha derepresses hypoxia-inducible factor-1 during moderate hypoxia by sequestering factor inhibiting hypoxiainducible factor from hypoxia-inducible factor $1 \alpha$. FEBS J. 2009;276:3470-80.

14. Feldser D, Agani F, Iyer NV, Pak B, Ferreira G, Semenza GL. Reciprocal positive regulation of hypoxia-inducible factor $1 \alpha$ and insulin-like growth factor 2. Cancer Res. 1999;59:3915-8.

15. Hellwig-Bürgel T, Rutkowski K, Metzen E, Fandrey J, Jelkmann W. Interleukin-1 $\beta$ and tumor necrosis factor- $\alpha$ stimulate DNA binding of hypoxiainducible factor-1. Blood. 1999;94:1561-7.

16. Moon EJ, Jeong CH, Jeong JW, Kim KR, Yu DY, Murakami S, et al. Hepatitis B virus $X$ protein induces angiogenesis by stabilizing hypoxiainducible factor-1 $\alpha$. FASEB J. 2004;18:382-4.
17. Karapetsas A, Giannakakis A, Pavlaki M, Panayiotidis M, Sandaltzopoulos R, Galanis A. Biochemical and molecular analysis of the interaction between ERK2 MAP kinase and hypoxia inducible factor- $1 \alpha$. Int $\mathrm{J}$ Biochem Cell Biol. 2011;43:1582-90.

18. Frede S, Stockmann C, Freitag P, Fandrey J. Bacterial lipopolysaccharide induces HIF-1 activation in human monocytes via p44/42 MAPK and NFkappaB. Biochem J. 2006;396:517-27.

19. Sumbayev VV. PI3 kinase and direct S-nitrosation are involved in down-regulation of apoptosis signalregulating kinase 1 during LPS-induced Toll-like receptor 4 signalling. Immunol Lett. 2008;115:126-30.

20. Nicholas SA, Sumbayev VV. The involvement of hypoxia-inducible factor $1 \alpha$ in Toll-like receptor 7/8-mediated inflammatory response. Cell Res. 2009; 19:973-83.

21. Gibbs BF, Yasinska IM, Pchejetski D, Wyszynski RW, Sumbayev VV. Differential control of hypoxiainducible factor 1 activity during pro-inflammatory reactions of human haematopoietic cells of myeloid lineage. Int J Biochem Cell Biol. 2012;44:1739-49.

22. Imtiyaz HZ, Simon MC. Hypoxia-inducible factors as essential regulators of inflammation. Curr Top Microbiol Immunol. 2010;345:105-20.

23. Zhou J, Schmid T, Brune B. Tumor necrosis factor- $\alpha$ causes accumulation of a ubiquitinated form of hypoxia inducible factor- $1 \alpha$ through a nuclear factor- $\kappa \mathrm{B}-$ dependent pathway. Mol Biol Cell. 2003;14:2216-25.

24. Jung Y-J, Isaacs JS, Lee S, Trepel J, Neckers L. IL-1 $\beta$ mediated up-regulation of HIF- $1 \alpha$ via an NFKB/ COX-2 pathway identifies HIF-1 as a critical link between inflammation and oncogenesis. FASEB J. 2003;17:2115-7.

25. Silver IA. Tissue $\mathrm{PO} 2$ changes in acute inflammation. Adv Exp Med Biol. 1977;94:769-74.

26. Hong SW, Yoo JW, Kang HS, Kim S, Lee DK. HIF-1 $\alpha$ dependent gene expression program during the nucleic acid-triggered antiviral innate immune responses. Mol Cells. 2009;27:243-50.

27. Werth N, Beerlage C, Rosenberger C, Yazdi AS, Edelmann M, Amr A, et al. Activation of hypoxia inducible factor 1 is a general phenomenon in infections with human pathogens. PLoS ONE. 2010;5:e11576.

28. Zarember KA, Malech HL. HIF-1 $\alpha$ : a master regulator of innate host defenses? J Clin Invest. 2005;115:1702-4. 
29. Bosco MC, Varesio L. Dendritic cell reprogramming by the hypoxic environment. Immunobiology. 2012;217:1241-9.

30. Kong T, Eltzschig HK, Karhausen J, Colgan SP, Shelley CS. Leukocyte adhesion during hypoxia is mediated by HIF-1-dependent induction of $\beta 2$ integrin gene expression. Proc Natl Acad Sci USA. 2004;101:10440-5.

31. Zhou J, Dehne N, Brüne B. Nitric oxide causes macrophage migration via the HIF-1-stimulated small GTPases Cdc42 and Rac1. Free Radic Biol Med. 2009;47:741-9.

32. Schioppa T, Uranchimeg B, Saccani A, Biswas SK, Doni A, Rapisarda A, et al. Regulation of the chemokine receptor CXCR4 by hypoxia. J Exp Med. 2003;198:1391-402.

33. Bosco MC, Reffo G, Puppo M, Varesio L. Hypoxia inhibits the expression of the CCR5 chemokine receptor in macrophages. Cell Immunol. 2004;228:1-7.

34. Walmsley SR, Cadwallader KA, Chilvers ER. The role of HIF- $1 \alpha$ in myeloid cell inflammation. Trends Immunol. 2005;26:434-9.

35. Elks PM, van Eeden FJ, Dixon G, Wang X, ReyesAldasoro CC, Ingham PW, et al. Activation of hypoxia-inducible factor- $1 \alpha$ (Hif- $1 \alpha$ ) delays inflammation resolution by reducing neutrophil apoptosis and reverse migration in a zebrafish inflammation model. Blood. 2011;118:712-22.

36. Roiniotis J, Dinh H, Masendycz P, Turner A, Elsegood CL, Scholz GM, et al. Hypoxia prolongs monocyte/macrophage survival and enhanced glycolysis is associated with their maturation under aerobic conditions. J Immunol. 2009;182:7974-81.

37. Kuhlicke J, Frick JS, Morote-Garcia JC, Rosenberger P, Eltzschig HK. Hypoxia inducible factor (HIF)-1 coordinates induction of Toll-like receptors TLR2 and TLR6 during hypoxia. PLoS ONE. 2007;2:e1364.

38. Kim SY, Choi YJ, Joung SM, Lee BH, Jung Y-S, Lee JY. Hypoxic stress up-regulates the expression of Toll-like receptor 4 in macrophages via hypoxiainducible factor. Immunology. 2010;129:516-24.

39. Anand RJ, Gribar SC, Li J, Kohler JW, Branca MF, Dubowski T, et al. Hypoxia causes an increase in phagocytosis by macrophages in a HIF-1 $\alpha$ dependent manner. J Leuk Biol. 2007;82:1257-65.

40. Walmsley SR, Cowburn AS, Clatworthy MR, Morrell NW, Roper EC, Singleton V, et al. Neutrophils from patients with heterozygous germline mutations in the von Hippel Lindau protein (pVHL) display delayed apoptosis and enhanced bacterial phagocytosis. Blood. 2006;108:3176-8.

41. Peyssonnaux C, Datta V, Cramer T, Doedens A, Theodorakis EA, Gallo RL, et al. HIF- $1 \alpha$ expression regulates the bactericidal capacity of phagocytes. J Clin Invest. 2005;115:1806-15.

42. Berger EA, McClellan SA, Vistisen KS, Hazlett LD. HIF- $1 \alpha$ is essential for effective PMN bacterial killing, antimicrobial peptide production and apoptosis in Pseudomonas aeruginosa keratitis. PLoS Pathog. 2013;9:e1003457.

43. Zinkernagel AS, Peyssonnaux C, Johnson RS, Nizet V. Pharmacologic augmentation of hypoxiainducible factor- $1 \alpha$ with mimosine boosts the bactericidal capacity of phagocytes. J Infect Dis. 2008;197:214-7.

44. Okumura CYM, Hollands A, Tran DN, Olson J, Dahesh S, Köckritz-Blickwede MV, et al. A new pharmacological agent (AKB-4924) stabilizes hypoxia inducible factor-1 (HIF-1) and increases skin innate defenses against bacterial infection. J Mol Med. 2012;90:1079-89.

45. Mecklenburgh KI, Walmsley SR, Cowburn AS, Wiesener M, Reed BJ, Upton PD, et al. Involvement of a ferroprotein sensor in hypoxiamediated inhibition of neutrophil apoptosis. Blood. 2002;100:3008-16.

46. McInturff AM, Cody MJ, Elliott EA, Glenn JW, Rowley JW, Rondina MT, et al. Mammalian target of rapamycin regulates neutrophil extracellular trap formation via induction of hypoxia-inducible factor

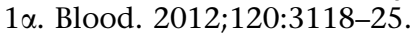

47. Branitzki-Heinemann K, Okumura CY, Völlger L, Kawakami Y, Kawakami T, Naim HY, et al. A novel role for the transcription factor HIF-1 $\alpha$ in the formation of mast cell extracellular traps. Biochem J. 2012;446:159-63.

48. McLellan AD, Kämpgen E. Functions of myeloid and lymphoid dendritic cells. Immunol Lett. 2000;72:101-5.

49. Randolph GJ, Inaba K, Robbiani DF, Steinman RM, Muller WA. Differentiation of phagocytic monocytes into lymph node dendritic cells in vivo. Immunity. 1999;11:753-61.

50. Shortman K, Naik SH. Steady-state and inflammatory dendritic-cell development. Nat Rev Immunol. 2007;7:19-30.

51. Rama I, Bruene B, Torras J, Koehl R, Cruzado JM, Bestard $\mathrm{O}$, et al. Hypoxia stimulus: an adaptive immune response during dendritic cell maturation. Kidney Int. 2008;2008(73):816-25. 
52. Goth SR, Chu RA, Pessah IN. Oxygen tension regulates the in vitro maturation of GM-CSF expanded murine bone marrow dendritic cells by modulating class II MHC expression. J Immunol Methods. 2006;308:179-91.

53. Jantsch J, Chakravortty D, Turza N, Prechtel AT, Buchholz B, Gerlach RG, et al. Hypoxia and hypoxiainducible factor- $1 \alpha$ modulate lipopolysaccharideinduced dendritic cell activation and function. J Immunol. 2008;180:4697-705.

54. Spirig R, Djafarzadeh S, Regueira T, Shaw SG, von Garnier C, Takala J, et al. Effects of TLR Agonists on the hypoxia-regulated transcription factor HIF-1 $\alpha$ and dendritic cell maturation under normoxic conditions. PLoS ONE. 2010;5:e10983.

55. Yang M, Ma C, Liu S, Sun J, Shao Q, Gao W, et al. Hypoxia skews dendritic cells to a $\mathrm{T}$ helper type 2-stimulating phenotype and promotes tumour cell migration by dendritic cell-derived osteopontin. Immunology. 2009;128:e237-49.

56. Ogino T, Onishi H, Suzuki H, Morisaki T, Tanaka M, Katano M. Inclusive estimation of complex antigen presentation functions of monocyte-derived dendritic cells differentiated under normoxia and hypoxia conditions. Cancer Immunol Immunother. 2012;61:409-24.

57. Elia AR, Cappello P, Puppo M, Fraone T, Vanni C, Eva A, et al. Human dendritic cells differentiated in hypoxia down-modulate antigen uptake and change their chemokine expression profile. J Leuk Biol. 2008;84:1472-82.

58. Ricciardi A, Elia AR, Cappello P, Puppo M, Vanni C, Fardin $\mathrm{P}$, et al. Transcriptome of hypoxic immature dendritic cells: modulation of chemokine/receptor expression. Mol Cancer Res. 2008;6:175-85.

59. Pierobon D, Bosco MC, Blengio F, Raggi F, Eva A, Filippi $\mathrm{M}$, et al. Chronic hypoxia reprograms human immature dendritic cells by inducing a proinflammatory phenotype and TREM-1 expression. Eur J Immunol. 2013;43:949-66.

60. Mancino A, Schioppa T, Larghi P, Pasqualini F, Nebuloni M, Chen IH, et al. Divergent effects of hypoxia on dendritic cell functions. Blood. 2008;112:3723-34.

61. Zhao W, Darmanin S, Fu Q, Chen J, Cui H, Wang J, et al. Hypoxia suppresses the production of matrix metalloproteinases and the migration of human monocyte-derived dendritic cells. Eur J Immunol. 2005;35:3468-77.

62. Qu X, Yang M-X, Kong B-H, Qi L, Lam QLK, Yan S, et al. Hypoxia inhibits the migratory capacity of human monocyte-derived dendritic cells. Immunol Cell Biol. 2005;83:668-73.

63. Rahat MA, Marom B, Bitterman H, Weiss-Cerem L, Kinarty A, Lahat N. Hypoxia reduces the output of matrix metalloproteinase-9 (MMP-9) in monocytes by inhibiting its secretion and elevating membranal association. J Leuk Biol. 2006;79:706-18.

64. Bosseto MC, Palma PVB, Covas DT, Giorgio S. Hypoxia modulates phenotype, inflammatory response, and leishmanial infection of human dendritic cells. APMIS. 2010;2010(118):108-14.

65. Lahat N, Rahat MA, Ballan M, Weiss-Cerem L, Engelmayer M, Bitterman H. Hypoxia reduces CD80 expression on monocytes but enhances their LPSstimulated TNF- $\alpha$ secretion. J Leuk Biol. 2003;74:197-205.

66. Acosta-Iborra B, Elorza A, Olazabal IM, MartínCofreces NB, Martin-Puig S, Miró M, et al. Macrophage oxygen sensing modulates antigen presentation and phagocytic functions involving IFN- $\gamma$ production through the HIF- $1 \alpha$ transcription tactor. J Immunol. 2009;182:3155-64.

67. Werno C, Menrad H, Weigert A, Dehne N, Goerdt S, Schledzewski K, et al. Knockout of HIF- $1 \alpha$ in tumorassociated macrophages enhances M2 polarization and attenuates their pro-angiogenic responses. Carcinogenesis. 2010;31:1863-72.

68. Blengio F, Raggi F, Pierobon D, Cappello P, Eva A, Giovarelli $\mathrm{M}$, et al. The hypoxic environment reprograms the cytokine/chemokine expression profile of human mature dendritic cells. Immunobiology. 2013;218:76-89.

69. Murata Y, Ohteki T, Koyasu S, Hamuro J. IFN- $\gamma$ and pro-inflammatory cytokine production by antigenpresenting cells is dictated by intracellular thiol redox status regulated by oxygen tension. Eur J Immunol. 2002;32:2866-73.

70. Wobben R, Huesecken Y, Lodewick C, Gibbert K, Fandrey J, Winning S. Role of hypoxia inducible factor- $1 \alpha$ for interferon synthesis in mouse dendritic cells. Biol Chem. 2013;394:495-505.

71. Longhi MP, Trumpfheller C, Idoyaga J, Caskey M, Matos I, Kluger C, et al. Dendritic cells require a systemic type I interferon response to mature and induce CD4+ Th1 immunity with poly IC as adjuvant. J Exp Med. 2009;206:1589-602.

72. Doedens AL, Stockmann C, Rubinstein MP, Liao D, Zhang N, DeNardo DG, et al. Macrophage expression of hypoxia-inducible factor-1 alpha suppresses T-cell function and promotes tumor progression. Cancer Res. 2010;70:7465-75. 
73. Jantsch J, Wiese M, Schödel J, Castiglione K, Gläsner $\mathrm{J}$, Kolbe $\mathrm{S}$, et al. Toll-like receptor activation and hypoxia use distinct signaling pathways to stabilize hypoxia-inducible factor $1 \alpha$ (HIF1 $\alpha$ ) and result in differential HIF1 $\alpha$-dependent gene expression. J Leuk Biol. 2011;90:551-62.

74. Sun J, Zhang Y, Yang M, Xie Q, Li Z, Dong Z, et al. Hypoxia induces T-cell apoptosis by inhibiting chemokine $\mathrm{C}$ receptor 7 expression: the role of adenosine receptor $\mathrm{A}(2)$. Cell Mol Immunol. 2010;7:77-82.

75. Larbi A, Cabreiro F, Zelba H, Marthandan S, Combet E, Friguet B, et al. Reduced oxygen tension results in reduced human $\mathrm{T}$ cell proliferation and increased intracellular oxidative damage and susceptibility to apoptosis upon activation. Free Radic Biol Med. 2010;48:26-34.

76. Conforti L, Petrovic M, Mohammad D, Lee S, Ma Q, Barone $S$, et al. Hypoxia regulates expression and activity of Kv1.3 channels in T lymphocytes: a possible role in $\mathrm{T}$ cell proliferation. J Immunol. 2003;170:695-702.

77. Lukashev D, Sitkovsky M. Preferential expression of the novel alternative isoform I.3 of hypoxiainducible factor $1 \alpha$ in activated human $\mathrm{T}$ lymphocytes. Hum Immunol. 2008;69:421-5.

78. Georgiev P, Belikoff BB, Hatfield S, Ohta A, Sitkovsky MV, Lukashev D. Genetic deletion of the HIF- $1 \alpha$ isoform I. 1 in T cells enhances anti-bacterial immunity and improves survival in a murine peritonitis model. Eur J Immunol. 2013;43:655-66.

79. Lukashev D, Klebanov B, Kojima H, Grinberg A, Ohta A, Berenfeld L, et al. Cutting edge: hypoxiainducible factor $1 \alpha$ and its activation-inducible short isoform I.1 negatively regulate functions of CD4+ and CD8+ T lymphocytes. J Immunol. 2006;177:4962-5.

80. Fontenot JD, Gavin MA, Rudensky AY. Foxp3 programs the development and function of CD4 + CD25 + regulatory $\mathrm{T}$ cells. Nat Immunol. 2003;4:330-6.

81. Ivanov II, McKenzie BS, Zhou L, Tadokoro CE, Lepelley A, Lafaille JJ, et al. The orphan nuclear receptor ROR $\gamma$ t directs the differentiation program of proinflammatory IL-17+ T helper cells. Cell. 2006;126:1121-33.

82. Clambey ET, McNamee EN, Westrich JA, Glover LE, Campbell EL, Jedlicka P, et al. Hypoxia-inducible factor-1 $\alpha$-dependent induction of FoxP3 drives regulatory $\mathrm{T}$-cell abundance and function during inflammatory hypoxia of the mucosa. Proc Natl Acad Sci USA. 2012;109:E2784-93.
83. Ben-Shoshan J, Maysel-Auslender S, Mor A, Keren G, George J. Hypoxia controls CD4+ CD25+ regulatory T-cell homeostasis via hypoxiainducible factor-1 $\alpha$. Eur J Immunol. 2008;38:2412-8.

84. Higashiyama M, Hokari R, Hozumi H, Kurihara C, Ueda $\mathrm{T}$, Watanabe $\mathrm{C}$, et al. HIF-1 in $\mathrm{T}$ cells ameliorated dextran sodium sulfate-induced murine colitis. J Leuk Biol. 2012;91:901-9.

85. Ikejiri A, Nagai S, Goda N, Kurebayashi Y, OsadaOka M, Takubo K, et al. Dynamic regulation of Th17 differentiation by oxygen concentrations. Int Immunol. 2012;24:137-46.

86. Dang EV, Barbi J, Yang H-Y, Jinasena D, Yu H, Zheng Y, et al. Control of TH17/Treg balance by hypoxia-inducible factor 1 . Cell. 2011;146:772-84.

87. Shi LZ, Wang R, Huang G, Vogel P, Neale G, Green DR, et al. HIF1 $\alpha$-dependent glycolytic pathway orchestrates a metabolic checkpoint for the differentiation of TH17 and Treg cells. J Exp Med. 2011;208:1367-76.

88. Kominsky DJ, Campbell EL, Colgan SP. Metabolic shifts in immunity and inflammation. J Immunol. 2010;184:4062-8.

89. Haeberle HA, Dürrstein C, Rosenberger P, Hosakote YM, Kuhlicke J, Kempf VAJ, et al. Oxygenindependent stabilization of hypoxia inducible factor (HIF)-1 during RSV Infection. PLoS ONE. 2008;3:e3352.

90. Hwang IIL, Watson IR, Der SD, Ohh M. Loss of VHL confers hypoxia-inducible factor (HIF)-dependent resistance to vesicular stomatitis virus: role of HIF in antiviral response. J Virol. 2006;80:10712-23.

91. Cho IR, Koh SS, Min HJ, Park EH, Ratakorn S, Jhun $\mathrm{BH}$, et al. Down-regulation of HIF- $1 \alpha$ by oncolytic reovirus infection independently of VHL and p53. Cancer Gene Ther. 2010;17:365-72.

92. Lungu GF, Stoica G, Wong PKY. Down-regulation of Jab1, HIF-1 $\alpha$, and VEGF by Moloney murine leukemia virus-ts1 infection: a possible cause of neurodegeneration. J Neurovirol. 2008;14:239-51.

93. Rupp J, Gieffers J, Klinger M, Van Zandbergen G, Wrase $\mathrm{R}$, Maass $\mathrm{M}$, et al. Chlamydia pneumoniae directly interferes with HIF- $1 \alpha$ stabilization in human host cells. Cell Microbiol. 2007;9:2181-91.

94. Legendre C, Reen FJ, Mooij MJ, McGlacken GP, Adams C, O'Gara F. Pseudomonas aeruginosa alkyl quinolones repress hypoxia-inducible factor 1 (HIF1) signaling through HIF-1 $\alpha$ degradation. Infect Immun. 2012;80:3985-92. 
95. Yoo YG, Oh SH, Park ES, Cho H, Lee N, Park H, et al. Hepatitis B virus $X$ protein enhances transcriptional activity of hypoxia-inducible factor- $1 \alpha$ through activation of mitogen-activated protein kinase pathway. J Biol Chem. 2003;278:39076-84.

96. Cai QL, Knight JS, Verma SC, Zald P, Robertson ES. EC5S ubiquitin complex is recruited by KSHV latent antigen LANA for degradation of the VHL and p53 tumor suppressors. PLoS Pathog. 2006;2:e116.

97. Kondo S, Seo SY, Yoshizaki T, Wakisaka N, Furukawa M, Joab I, et al. EBV latent membrane protein 1 up-regulates hypoxia-inducible factor $1 \alpha$ through Siah1-mediated down-regulation of prolyl hydroxylases 1 and 3 in nasopharyngeal epithelial cells. Cancer Res. 2006;66:9870-7.

98. Deshmane SL, Mukerjee R, Fan S, Del Valle L, Michiels C, Sweet $\mathrm{T}$, et al. Activation of the oxidative stress pathway by HIV-1 Vpr leads to induction of hypoxia-inducible factor $1 \alpha$ expression. J Biol Chem. 2009;284(17):11364-73.

99. Piña-Oviedo S, Khalili K, Del Valle L. Hypoxia inducible factor- $1 \alpha$ activation of the JCV promoter: role in the pathogenesis of progressive multifocal leukoencephalopathy. Acta Neuropathol. 2009;118:235-47.

100. Polcicova K, Hrabovska Z, Mistrikova J, Tomaskova J, Pastorek J, Pastorekova S, et al. Up-regulation of Murid herpesvirus 4 ORF50 by hypoxia: possible implication for virus reactivation from latency. Virus Res. 2008;132:257-62.

101. Jiang J-H, Wang N, Li A, Liao W-T, Pan Z-G, Mai S-J, et al. Hypoxia can contribute to the induction of the Epstein-Barr virus (EBV) lytic cycle. J Clin Virol. 2006;37:98-103.

102. Keely S, Glover LE, Weissmueller T, MacManus CF, Fillon S, Fennimore B, et al. Hypoxia-inducible factor-dependent regulation of platelet-activating factor receptor as a route for Gram-positive bacterial translocation across epithelia. Mol Biol Cell. 2010;21:538-46.

103. Spear W, Chan D, Coppens I, Johnson RS, Giaccia A, Blader IJ. The host cell transcription factor hypoxiainducible factor 1 is required for Toxoplasma gondii growth and survival at physiological oxygen levels. Cell Microbiol. 2006;8:339-52.

104. Wiley M, Sweeney KR, Chan DA, Brown KM, McMurtrey C, Howard EW, et al. Toxoplasma gondii activates hypoxia-inducible factor (HIF) by stabilizing the HIF-1 $\alpha$ subunit via type I activin-like receptor kinase receptor signaling. J Biol Chem. 2010;285:26852-60.

105. Degrossoli A, Bosetto MC, Lima CBC, Giorgio S. Expression of hypoxia-inducible factor $1 \alpha$ in mononuclear phagocytes infected with Leishmania amazonensis. Immunol Lett. 2007;114:119-25.

106. Singh AK, Mukhopadhyay C, Biswas S, Singh VK, Mukhopadhyay CK. Intracellular pathogen Leishmania donovani activates hypoxia inducible factor-1 by dual mechanism for survival advantage within macrophage. PLoS ONE. 2012;7:e38489.

107. Zhao S, Wu J. Hypoxia inducible factor stabilization as a novel strategy to treat anemia. Curr Med Chem. 2013;20:2697-711.

108. Peyssonnaux C, Cejudo-Martin P, Doedens A, Zinkernagel AS, Johnson RS, Nizet V. Cutting edge: essential role of hypoxia inducible factor- $1 \alpha$ in development of lipopolysaccharide-induced sepsis. J Immunol. 2007;178:7516-9.

109. Thiel M, Caldwell CC, Kreth S, Kuboki S, Chen P, Smith P, et al. Targeted deletion of HIF-1 $\alpha$ gene in T cells prevents their inhibition in hypoxic inflamed tissues and improves septic mice survival. PLoS ONE. 2007;2:e853.

110. Schafer ST, Frede S, Winning S, Bick A, Roshangar P, Fandrey J, et al. Hypoxia-inducible factor and target gene expression are decreased in patients with sepsis: prospective observational clinical and cellular studies. Anesthesiology. 2013;118:1426-36.

111. Keely S, Campbell EL, Baird AW, Hansbro PM, Shalwitz RA, Kotsakis A, et al. Contribution of epithelial innate immunity to systemic protection afforded by prolyl hydroxylase inhibition in murine colitis. Mucosal Immunol. 2014;7:114-23.

112. Campbell EL, Bruyninckx WJ, Kelly CJ, Glover LE, McNamee EN, Bowers BE, et al. Transmigrating neutrophils shape the mucosal microenvironment through localized oxygen depletion to influence resolution of inflammation. Immunity. 2014;40:66-77.

113. Weigert A, Weichand B, Sekar D, Sha W, Hahn C, Mora $J$, et al. HIF- $1 \alpha$ is a negative regulator of plasmacytoid DC development in vitro and in vivo. Blood. 2012;120:3001-6. 
114. Bhandari T, Olson J, Johnson RS, Nizet V. HIF1alpha influences myeloid cell antigen presentation and response to subcutaneous OVA vaccination. J Mol Med (Berlin). 2013;91:1199-205.

115. Loboda A, Jozkowicz A, Dulak J. HIF-1 and HIF-2 transcription factors-similar but not identical. Mol Cells. 2010;29:435-42.

116. Loboda A, Jozkowicz A, Dulak J. HIF-1 versus HIF2 -is one more important than the other? Vascul Pharmacol. 2012;56:245-51.

117. Florczyk U, Czauderna S, Stachurska A, Tertil M, Nowak W, Kozakowska M, et al. Opposite effects of HIF- $1 \alpha$ and HIF- $2 \alpha$ on the regulation of IL-8 expression in endothelial cells. Free Radic Biol Med. 2011;51:1882-92.
118. Fang H-Y, Hughes R, Murdoch C, Coffelt SB, Biswas SK, Harris AL, et al. Hypoxia-inducible factors 1 and 2 are important transcriptional effectors in primary macrophages experiencing hypoxia. Blood. 2009;114:844-59.

119. Loboda A, Stachurska A, Florczyk U, Rudnicka D, Jazwa A, Wegrzyn J, et al. HIF-1 induction attenuates Nrf2-dependent IL-8 expression in human endothelial cells. Antioxid Redox Signal. 2009;11:1501-17. 